\title{
Mental Health Literacy amongst college students : a community based study
}

\author{
Bhavesh Lakdawala ${ }^{1}$, Ganpat K. Vankar ${ }^{2}$ \\ ${ }^{1}$ Associate Professor, Department of Psychiatry, GMERS Medical College and General Hospital, Gandhinagar, \\ Gujarat, India. \\ ${ }^{2}$ Professor, Department of Psychiatry, Sri Aurobindo Institute of Medical Sciences, Indore, Madhya Pradesh, India. \\ E-mail-dr_bmlakdawala@yahoo.co.in
}

\begin{abstract}
Background: High level of mental health literacy which includes adequate knowledge and positive attitudes in medical, psychology and sociology students towards psychiatric illnesses would make early recognition of and appropriate intervention in these disorders more likely. Our aim was to assess knowledge and attitude of college students of three faculties-medical, psychology and sociology towards the mentally ill and socio-demographic correlates.

Methodology: A survey method was employed in Medical and Arts Colleges. One medical college and 5 arts colleges were surveyed regarding students' attitude towards psychiatric illness using National Health Service (NHS) survey questionnaire. Total 1231 completed responses were analyzed. Statistical analysis methods used were Chi square test, Student's t test and One-way ANOVA.

Results: There was association between present and past contact with someone with mental health problem and future willingness to have relationship with the same.

Conclusions: Areas of deficits in attitude in students can be targeted for further educational interventions and training so that positive attitudes can be inculcated in future health professionals which will ultimately benefit our society.
\end{abstract}

Key Words: Attitude, Medical students, Psychology students, Sociology students, NHS Survey, Mentally ill.

(Paper received $-30^{\text {th }}$ July 2016, Peer review completed $-2^{\text {th }}$ August 2016, Accepted $-8^{\text {th }}$ September 2016)

\section{INTRODUCTION}

The term "Mental health literacy" refers to knowledge and beliefs about mental disorders which aid their recognition management and prevention. Mental health literacy includes the ability to recognize specific disorders, knowing how to seek mental health information; knowledge of risk factors and causes, of self treatments and of professional help available; and attitudes that promote recognition and appropriate help seeking [1]. Psychiatric disorders are universal and affect more than $25 \%$ people at some time during their lifetime [2]. Many studies have shown that negative attitudes towards mental illness are widespread [3-4]. The stigma associated with mental illness may also delay seeking treatment [5]. The belief that mental illness is incurable or self inflicted can also be damaging leading to patients not being referred for appropriate mental health care. Attitudes influence both professional and personal behavior. In particular stigma and discrimination associated with mental illness and expressed by mental health professionals results in the under use of mental health services [6]. Stigma leads to social exclusion, non-compliance to effective treatment and major obstacle to recovery. Several studies report that stigma is universal and involve not only lay persons but also various health professionals including psychiatrists, other doctors, psychologists, nursing personnel and health workers [7]. 
There may be various reasons for negative attitude. Lack of accurate information about mental illness, lack of contact with individuals with mental illness and lack of familiarity might be one of the most important reasons of this [8]. Research shows greater exposure to and working with mentally ill patients during medical training decreases fear and creates a positive attitude towards caring for the mentally ill [9-10].

\section{Indian Studies on Attitude towards mental illness}

Several Indian studies of medical students, medical professionals, and general public have concluded gaps in knowledge and stigma related to patients suffering from psychiatric disorders. In a study of 210 undergraduate medical students, the undergraduate medical students had multiple lacunae in their knowledge toward psychiatry, psychiatric disorders, psychiatric patients and psychiatric treatment. A potential contributory fact could be the neglect of psychiatry as a discipline at the undergraduate level [11]. Undergraduate teaching is not given importance. Greater exposure to and working with mentally ill during medical training decreases fear and creates positive attitude [12]. People who had psychiatric disorders believed that the mental disorders were thought to be because of loss of semen or vaginal secretion, less sexual desire, excessive masturbation, god's punishment for their past sins and polluted air were mentioned as perceived causes [13]. Researchers studied knowledge and attitude towards mental illness in general public of Southern India in 100 participants. They found poor knowledge score on most of the items. Regarding attitude only $18 \%$ stated that they would visit a psychiatrist if had an emotional problem; Sixty percent $(60 \%)$ were afraid of someone with mental health problem as neighbor and $55 \%$ thought marriage can treat mental illness. Only $25 \%$ were willing to maintain friendship with someone with mental illness and 55\% felt ashamed to mention someone in family who has mental illness [14].

Studies have concluded that urban and rural societies differ in type of stigma. Rural societies had a punitive model towards the severely mentally ill, while the urban group expressed a liberal view of severe mental illness. Urban Indians showed a strong link between stigma and not wishing to work with a mentally ill individual, whereas no such link existed for rural Indians [15]. In a study reported that urban respondents felt the need to hide their illness and avoided illness histories in job applications while rural respondents experienced more ridicule, shame and discrimination [16]. The study of marital status in patients with schizophrenia shows that the overall rate of marrying and intact marriages were high in Indian patients. Males were seen to marry less often, but once they did so had less of broken marriages. A continuous/relapsing course of illness seems to reduce the prospect of getting married in both sexes. It is seen that breaking of marriage, when it occurs, did so more commonly if the wife was ill and childless. The high rates of marriage and intact marriage, more marriages breaking when wife was sick all seem to reflect the socio-cultural attitudes and practices regarding marriage in the predominantly Hindu Indian society more than any illness or patient related variables [17]. Other researchers have concluded that Psychiatry is given very less importance in the Indian undergraduate medical curriculum and this affects the attitudes of students toward psychiatry and mentally ill patients. In a study aimed at surveying the attitude of undergraduate medical students and interns towards psychiatry and mentally ill patients, on the attitude toward psychiatry scale, respondents expressed views on psychiatry as it being an unscientific specialty. Psychiatrists were considered as poor role models and psychiatric teaching was thought to be of low quality and psychiatry was overall the least preferred career choice [18]. In a village health worker study, socio-economic interventions provided by family, friends and neighbors were considered to be most helpful. Local VHWs and doctors were also viewed as potentially helpful, but psychiatrists less so. Approximately half of the sample thought that dealing with the problem alone would be helpful. Special diets, tonics, appetite stimulants and sleeping pills were also strongly endorsed, but awareness of psychiatric medications was negligible [19].

The aim of the current study was to study the attitude of college students of various faculties i.e medical, psychology and sociology towards the mentally ill. 


\section{METHODOLOGY}

One Medical college and 5 Arts colleges' students were surveyed regarding their attitudes towards psychiatric illness using the NHS Survey Questionnaire. In Medical College students of each year were surveyed in separate sessions while in Arts colleges students of all years surveyed in single session. Survey was done in July and August 2012.

Institution's ethics committee permission was taken before conducting the study. Purpose of the study was informed and consent was taken from participants before participation in the study. Participants were ensured of the confidentiality of the information provided. Study questionnaire was filled up by participants. After this, an educational session for mental health awareness was taken for 60 minutes.

Questionnaire comprised of Socio-demographic data, National Health Service (NHS) Survey Questionnaire.

National Health Service (NHS) Survey Questionnaire (U.K.) : The survey questionnaire included questions covered a range of other topics including descriptions of people with mental illness, relationships with people with MHPs, willingness to use different modalities of psychiatric treatment, personal experience of mental illness, readiness and ease of talking about MHP and perceptions of mental healthrelated stigma and discrimination. The Gujarati version was used where students were not well versed with English [20].

\section{STATISTICAL ANALYSIS}

Analysis was done using SPSS version 15 for windows. Descriptive statistics were computed first to ensure that all of the data were entered properly and to check for missing data. Qualitative data were analyzed by chi square test and quantitative data were analyzed by student's $t$ test and one-way ANOVA. P value of $<0.05$ was considered statistically significant.

\section{RESULTS}

A total of 1371 responses were received of which 140 responses were discarded as the information provided was inadequate leaving 1231 completed questionnaires for analysis.

Table 1: shows socio-demographic characteristics of the respondents

\begin{tabular}{|ll|}
\hline Variable & N (\%) \\
\hline Gender & \\
Female & $596(48.4)$ \\
Male & $635(51.6)$ \\
\hline Age & \\
Range & \\
Mean( SD) & $17-25$ years \\
& $19.38(1.87)$ \\
\hline Marital Status & \\
Unmarried & $1151(93.5)$ \\
Engaged & $49(4.0)$ \\
Married & $31(2.5)$ \\
& \\
\hline Year of Education & \\
First & $488(39.6)$ \\
Second & $368(29.9)$ \\
Third & $312(25.3)$ \\
Fifth & $63(5.1)$ \\
& \\
\hline
\end{tabular}




\begin{tabular}{|ll|}
\hline Faculty of Study & \\
Psychology & $443(36.0)$ \\
Sociology & $130(10.5)$ \\
MBBS & $658(53.5)$ \\
& \\
\hline $\begin{array}{l}\text { Residence } \\
\text { Ahmedabad (City) } \\
\text { Any Other }\end{array}$ & $728(59.1)$ \\
& $503(40.9)$ \\
\hline Monthly Income & \\
Rupees & $647(52.6)$ \\
19575 or more & $209(17.0)$ \\
9788 to 19575 & $229(18.6)$ \\
4894 to 9797 & $146(11.8)$ \\
up to 4893 & \\
\hline Domicile & \\
Urban & $1022(83.0)$ \\
Rural & $209(17.0)$ \\
& \\
\hline Religion & \\
Hindu & \\
Muslim & $1147(93.2)$ \\
Others & $49(4.0)$ \\
\hline Family Type & $35(2.9)$ \\
Joint & \\
Nuclear & $589(48.3)$ \\
& $642(51.7)$ \\
\hline
\end{tabular}

\section{Students' attitude towards mentally ill on National Health Service (NHS) Survey Questionnaire}

Perception of who can be considered mentally ill: Someone who is suffering from schizophrenia (67.3\%),someone who has severe bouts of depression(60.9\%), someone who was to be kept in mental hospital(53\%), someone with congenital brain functioning abnormality $(51.7 \%)$,someone who is prone to violence $(43.3 \%)$ were the more common responses.

Perception of mentally ill as violent and Intention for future relationship with mentally ill: Statistically significant difference was found for willingness to live nearby in future and belief of violence. No statistically significant difference was found for other parameters like willingness to live with, work with and willingness to be a friend with mentally ill.

\section{Personal experience of mental illness}

Relationships with people with MHPs (Present, Past and Future): The students reported contacts with someone with MHP as follows (present or past): living with (20.7\%), working with (11.2\%), living in neighborhood (24.6\%), close friendship (16.1\%).

They agreed or strongly agreed for the following in future: to live with $(31.8 \%)$, to work with $(45.1 \%)$, living in neighborhood (52.1\%), close friendship (66.9\%).

There was association between present and past contact with someone with MHP and future willingness to have relationship with someone with MHP was statistically significant $(\mathrm{p}<0.05)$. Thus present or past contact with mentally ill increases the tolerance for future relationship also. 
Table 2: Present and past contact with mentally ill and future intention

\begin{tabular}{|c|c|c|c|c|c|}
\hline \multirow{2}{*}{$\begin{array}{c}\text { Future } \\
\text { Relationship with } \\
\text { mentally ill }\end{array}$} & \multirow[t]{2}{*}{ Level of Agreement } & \multicolumn{2}{|c|}{ Present or Past Contact } & \multirow{2}{*}{$\begin{array}{c}\text { Chi } \\
\text { Square }\end{array}$} & \multirow[t]{2}{*}{$\mathrm{P}$ value } \\
\hline & & $\begin{array}{l}\text { Absent } \\
\mathrm{N}(\%)\end{array}$ & $\begin{array}{l}\text { Present } \\
\text { N (\%) }\end{array}$ & & \\
\hline Willing to live with & $\begin{array}{c}\text { Strongly Agree } \\
\text { Agree } \\
\text { Neutral } \\
\text { Disagree } \\
\text { Strongly Disagree } \\
\text { Total }\end{array}$ & $\begin{array}{c}53(5.2) \\
240(24.6) \\
374(38.4) \\
195(20.0) \\
114(11.7) \\
976\end{array}$ & $\begin{array}{l}27(10.6) \\
74(29.0) \\
76(29.8) \\
50(19.6) \\
28(11.0) \\
255\end{array}$ & 13.94 & $0.0075^{*}$ \\
\hline $\begin{array}{l}\text { Willing to work } \\
\text { with }\end{array}$ & $\begin{array}{c}\text { Strongly Agree } \\
\text { Agree } \\
\text { Neutral } \\
\text { Disagree } \\
\text { Strongly Disagree } \\
\text { Total }\end{array}$ & $\begin{array}{c}95(8.7) \\
379(34.7) \\
321(29.4) \\
210(19.2) \\
88(8.1) \\
1093\end{array}$ & $\begin{array}{c}25(18.1) \\
56(40.6) \\
27(19.6) \\
17(12.3) \\
13(9.4) \\
138\end{array}$ & 19.98 & $0.0005^{*}$ \\
\hline $\begin{array}{l}\text { Willing to live } \\
\text { nearby }\end{array}$ & $\begin{array}{c}\text { Strongly Agree } \\
\text { Agree } \\
\text { Neutral } \\
\text { Disagree } \\
\text { Strongly Disagree } \\
\text { Total }\end{array}$ & $\begin{array}{c}110(11.8) \\
352(37.9) \\
261(28.1) \\
141(15.2) \\
64(6.9) \\
928\end{array}$ & $\begin{array}{c}53(17.3) \\
128(42.4) \\
72(23.8) \\
32(10.6) \\
18(6.0) \\
303\end{array}$ & 11.98 & $0.0175^{*}$ \\
\hline $\begin{array}{l}\text { Willing to be a } \\
\text { friend }\end{array}$ & $\begin{array}{c}\text { Strongly Agree } \\
\text { Agree } \\
\text { Neutral } \\
\text { Disagree } \\
\text { Strongly Disagree } \\
\text { Total }\end{array}$ & $\begin{array}{c}265(25.7) \\
414(40.1) \\
192(18.6) \\
100(9.7) \\
62(6.0) \\
1033\end{array}$ & $\begin{array}{c}75(37.9) \\
70(35.4) \\
22(11.1) \\
18(9.1) \\
13(6.6) \\
198\end{array}$ & 15.42 & $0.0039 *$ \\
\hline
\end{tabular}

(All statistics done using the Chi square test, *significant $p<0.05$ )

Table 3: Attitude towards treatment for people with $\mathrm{MH}$ Problems

\begin{tabular}{|cc|}
\hline Statement & $\begin{array}{c}\text { Strongly } \\
\text { Agree/Agree (\%) }\end{array}$ \\
\hline Most people with MHPs want to have paid employment & 46.5 \\
\hline If a friend had a MHP, I know what advice to give them to get professional help & 74.4 \\
\hline Medication can be an effective treatment for people with MHPs & 53.4 \\
\hline Psychotherapy (e.g., talking therapy or counseling) can be an effective treatment for \\
people with MHPs
\end{tabular}


Table 4 : Perception of Usefulness of Different Types of Treatment and Faculty

\begin{tabular}{|ccccccc|}
\hline $\begin{array}{c}\text { Usefulness of } \\
\text { Type of } \\
\text { Treatment }\end{array}$ & $\begin{array}{c}\text { Level of } \\
\text { Agreement }\end{array}$ & $\begin{array}{c}\text { Psychology } \\
\text { Students } \\
(\mathrm{N}=443)\end{array}$ & $\begin{array}{c}\text { Sociology } \\
\text { Students } \\
(\mathrm{N}=130)\end{array}$ & $\begin{array}{c}\text { Medical } \\
\text { Students } \\
(\mathrm{N}=658)\end{array}$ & $\begin{array}{c}\text { Chi } \\
\text { Square }\end{array}$ & P value \\
\hline Medicines & Strongly Agree & $60(13.5)$ & $15(11.5)$ & $123(18.7)$ & 67.9 & $<0.0000001^{*}$ \\
& Agree & $127(28.7)$ & $37(28.5)$ & $295(44.9)$ & & \\
& Neutral & $124(28.0)$ & $38(29.2)$ & $125(19.0)$ & & \\
& Disagree & $97(21.9)$ & $30(23.1)$ & $101(15.4)$ & & \\
& Strongly Disagree & $35(7.9)$ & $10(7.7)$ & $14(2.0)$ & & \\
& & & & & & \\
\hline Psychotherapy & Strongly Agree & $135(30.6)$ & $28(21.5)$ & $357(54.3)$ & 136.8 & $<0.0000001^{*}$ \\
(Counseling) & Agree & $189(42.9)$ & $60(46.2)$ & $251(38.2)$ & & \\
& Neutral & $67(15.2)$ & $30(23.1)$ & $35(5.3)$ & & \\
& Disagree & $42(9.5)$ & $9(6.9)$ & $10(1.5)$ & & \\
& Strongly Disagree & $10(1.8)$ & $3(2.3)$ & $5(0.6)$ & & \\
& & & & & & \\
\end{tabular}

(All statistics done using the Chi square test, ${ }^{*} \mathrm{p}<0.05$ - significant)

Table 5: Perception of Conditions as Mental illness

\begin{tabular}{|cccccc|}
\hline Statement & $\begin{array}{c}\text { Agree } \\
\text { strongly } \\
(\mathbf{\%})\end{array}$ & $\begin{array}{c}\text { Agree } \\
\text { slightly } \\
(\%)\end{array}$ & $\begin{array}{c}\text { Neither agree nor } \\
\text { disagree } \\
(\%)\end{array}$ & $\begin{array}{c}\text { Disagree } \\
\text { slightly } \\
(\%)\end{array}$ & $\begin{array}{c}\text { Disagree } \\
\text { strongly } \\
(\%)\end{array}$ \\
\hline Depression & 30.6 & 43.3 & 12.5 & 9.7 & 3.9 \\
\hline Stress & 20.6 & 37.7 & 17.6 & 16.7 & 7.4 \\
\hline Schizophrenia & 51.7 & 30.0 & 12.6 & 3.8 & 1.9 \\
\hline Bipolar disorder & 35.8 & 25.4 & 26.6 & 8.7 & 3.4 \\
\hline Drug addiction & 20.1 & 27.3 & 19.0 & 20.8 & 12.7 \\
\hline Grief & 13.2 & 27.8 & 20.9 & 23.3 & 14.7 \\
\hline
\end{tabular}

The lowest percentage was for grief (13.2\%- Strongly agree), 33.5\% disagree with the statement that drug addiction is a type of mental illness while $47.4 \%$ agreeing that drug addiction was a type of mental illness. The percentage agreeing that stress was a type of mental illness was $57.7 \%$.

Closest person having mental illness

$58.7 \%$ of respondents said that they don't have any known who has or had some kind of mental illness. Close persons who has or has had some kind of mental illness were Acquaintances (11\%), Friend $(10.6 \%)$,other family members $(8 \%)$, immediate family members $(7 \%)$, work colleague $(2.7 \%)$, self $(1.1 \%)$ and partner $(1.4 \%)$

\section{Perception of percentage of people having MH Problem in the City (Ahmedabad)}

Respondents were asked what percentage of people in the city (Ahmedabad) they think might have a MHP at some point in their lives, and were given a list of options to choose from, ranging from 1 in 3 to 1 in 1000. The largest group of respondents (30.5\%) thought the percentage of people who would have a MHP at some point in their lives was 1 in $100.22 .2 \%$ thought that it was 1 in $50,19.8 \%$ said it was 1 in 10 . $17.9 \%$ said it was 1 in $1000.5 .9 \%$ and $3.7 \%$ thought that it was 1 in 4 and 1 in 3 respectively.

\section{Help-seeking}

$71.1 \%$ of respondents said that they would be likely to go to their GP for help. $48.8 \%$ of respondents said they are not comfortable talking to a friend or family member about their mental health, for example, telling them they had a mental health diagnosis and how it affects them. $51.2 \%$ of respondents said they are not comfortable talking to a teacher about their mental health, for example, telling them they had a mental health diagnosis and how it affects them. 


\section{DISCUSSION}

\section{Perception of who can be considered mentally ill}

Our study finding was similar to NHS study in 2011. The descriptions least likely to be selected were "someone who cannot be held responsible for his or her own actions" at $31.5 \%$ and "someone who is incapable of making simple decisions about his or her own life" at $28.1 \%$. These were also similar to NHS study. The descriptions "Someone prone to violence" was at $43.3 \%$ which was higher than NHS study in which this description was at 33\%. This description is very important as many studies [21-22] reported that if people had more belief about violence by mentally ill, more the social distance, fear, exclusion and stigma found for mentally ill.

Perception of mentally ill as violent and Intention for future relationship with mentally ill

Most studies on mental health literacy perceived mentally ill violent [23-24]. This is one of the most important factors that determine a person's attitude towards mentally ill as regards to social distance. Those who do not believe that mentally ill are violent, remain open to interaction with mentally ill without fear of harm.

\section{Personal experience of mental illness}

Willingness to live with someone with a MHP was 31.8\% which was lower than NHS study (56\%). 52.1\% would be willing either to live nearby to and $45.1 \%$ would be willing work with someone with a MHP. $66.9 \%$ would be willing to be a close friend with someone with MHP.

\section{Relation of Present or Past Contact with mentally ill and Intention for future relationship}

There was association between present and past contact with someone with MHP and future willingness to have relationship with someone with MHP. Thus close contact with mentally ill increases the tolerance for future relationship also.

\section{Attitudes towards treatment for people with MHPs}

The belief regarding medication usefulness was significantly lowered as compared to NHS study (79\% agreement) while that of psychotherapy (Counseling) was almost similar ( $81 \%$ agreement).

\section{Perception of Usefulness of Different Types of Treatment and Faculty}

Medication usefulness considered by medical students can be understood but nonmedical students' (psychology and sociology) higher disagreement regarding psychotherapy (counseling) usefulness is a matter of concern. There was no statistically significant difference between psychology and sociology students.

Regarding the prognosis statement that "Person suffering from mental illness can be completely cured" was agreed by $58.6 \%$ while in NHS study also $58 \%$ agreed and in Ireland survey $48 \%$ agreed. So we can say that still many were not optimistic about prognosis of mental illness.

\section{What would be considered as mental illness}

The pattern was similar in NHS Study. In that nearly nine out of ten agreeing schizophrenia as a mental illness, while in present study $62 \%$ agreeing strongly and $83 \%$ agreeing overall that schizophrenia is a mental illness. The finding regarding depression and bipolar disorder is similar to NHS study. The percentage agreeing that grief was a type of mental illness was (18\% - Strongly agree) similar to NHS study finding. The percentage agreeing that drug addiction was a type of mental illness was $46 \%$ is similar to NHS study finding. This suggests that many do not consider drug addiction as a MHP which is their ignorance and needs to be included in curriculum.

\section{Closest person having mental illness}

Individuals who knew someone who received treatment for a MHP, or who had personally received treatment, were more likely to endorse biological theories of causality and positive attitudes than those individuals without this familiarity to MHP [25-26].

\section{Help-seeking about a MHP}

$71.1 \%$ of respondents said that they would be likely to go to their GP for help. In NHS study this figure was $85 \%$. In most of the studies the general family physician was considered first point of professional contact which can be understood because of little stigma attached by contacting the family physician. $48.8 \%$ of respondents said they are not comfortable talking to a friend or family member about their mental health. In NHS study $70 \%$ said that they would feel comfortable talking to friend or family member 
about their mental health. $51.2 \%$ of respondents said they are not comfortable talking to a teacher about their mental health. In NHS study also $43 \%$ said that they would feel uncomfortable talking their employer about their mental health.

\section{Mental health-related stigma and discrimination}

91.7\% said that people with mental illness experience stigma and discrimination. Most students opined that people with mental illness experience stigma and discrimination. In NHS study also this figure was $85 \%$.

\section{Strength of the study}

- This is the first Indian study to use National Health Service (NHS) Survey Questionnaire in Indian population.

- This is the first study to compare mental health attitude in all three faculties of students namely medical, psychology and sociology in large sample population who will be the future mental health professionals dealing with mentally ill.

- All students were also imparted mental health awareness after collecting data in 1 hour session which can improve their knowledge and attitude.

\section{Limitations of the study}

- Sample size of sociology students were less.

- The study doesn't reflect the attitude towards MHP of general community.

\section{CONCLUSIONS}

We found significant negative attitude in students of all faculties. There were also perceptions of mentally ill as a violent person. Close contact with mentally ill in present or past was associated with willingness for future relationships to live with, to work with, to live in a neighborhood and to be a close friend with them. On treatment related issues, psychotherapy (counseling) in psychology and sociology students had lower agreement than medical students which is their main area of work dealing with mentally ill. Many participants were not comfortable telling to a friend, family member or teacher about their mental health issues. These all suggest that there are needs to improve mental health literacy in students' population who are future mental health professionals. A similar study can be conducted in general community, in people with all age group and different educational background using National Health Service (NHS) Survey Questionnaire. Areas of deficits in attitude in students can be targeted for further educational interventions and training. There is an immediate need to change psychiatry curriculum and training in undergraduate students in all faculties so that positive and tolerant attitude can be learnt from starting of the study only.

\section{REFERENCES}

1. Kelly CM, Jorm AF, Wright A. Improving mental health literacy as a strategy to facilitate early intervention for mental disorders. Med J Aust 2007;187(7 Suppl):S26-30.

2. Demyttenaere K, Bruffaerts R, Posada-Villa J, Gasquet I, Kovess V, Lepine J, Angermeyer MC, Bernert S, De Girolamo G, Morosini P, Polidori G. Prevalence, severity, and unmet need for treatment of mental disorders in the World Health Organization World Mental Health Surveys. JAMA 2004;291(21):2581-90.

3. Ross CA, Goldner EM. Stigma, negative attitudes and discrimination towards mental illness within the nursing profession: a review of the literature. J Psychiatr Ment Health Nurs 2009;16(6):558-67.

4. Corrigan PW, Watson AC. The paradox of self-stigma and mental illness. Clin Psychol Sci Pract 2002;9(1):35-53.

5. Corrigan PW, Watson AC, Barr L. The self-stigma of mental illness: Implications for self-esteem and selfefficacy. J Soc Clin Psychol 2006;25(8):875-84.

6. Angermeyer MC, Matschinger H. The stigma of mental illness: effects of labelling on public attitudes towards people with mental disorder. Acta Psychiatr Scand 2003;108(4):304-9.

7. Couture S, Penn D. Interpersonal contact and the stigma of mental illness: a review of the literature. J Ment Health 2003;12(3):291-305. 
8. Britt TW, Greene-Shortridge TM, Brink S, Nguyen QB, Rath J, Cox AL, Hoge CW, Castro CA. Perceived stigma and barriers to care for psychological treatment: Implications for reactions to stressors in different contexts. J Soc Clin Psychol 2008;27(4):317-35.

9. Baxter H, Singh SP, Standen P, Duggan C. The attitudes of 'tomorrow's doctors' towards mental illness and psychiatry: changes during the final undergraduate year. Med Educn 2001;35(4):381-3.

10. Calvert SH, Sharpe M, Power M, Lawrie SM. Does undergraduate education have an effect on Edinburgh medical students' attitudes to psychiatry and psychiatric patients?. J Nerv Ment Dis 1999;187(12):757-61.

11. Chawla JM, Balhara YP, Sagar R, Shivprakash. Undergraduate medical students' attitude toward psychiatry: A cross-sectional study. Indian J Psychiatry 2002;54:37-40.

12. Kattimani S. Undergraduate clinical posting in Psychiatry: Are we paying enough attention? Indian J Psychiatry 2010; 52(2):194-8.

13. Kishore J, Gupta A, Jiloha RC, Bantman P. Myths, beliefs and perceptions about mental disorders and health-seeking behavior in Delhi, India. Indian J Psychiatry 2011;53:324-9.

14. Ganesh K. Knowledge and Attitude of Mental Illness among General Public of Southern India. Natl J Comm Med 2011;2(1):175-9.

15. Jadhav S, Littlewood R, Ryder AG, Chakraborty A, Jain S, Barua M. Stigmatization of severe mental illness in India: against the simple industrialization hypothesis. Indian J Psychiatry 2007;49:189-94.

16. Loganathan S, Murthy SR. Experiences of stigma and discrimination endured by people suffering from schizophrenia. Indian J Psychiatry 2008;50:39-46.

17. Thara R, Srinivasan TN. Marriage and Gender in Schizophrenia. Indian J Psychiatry 1997;39(1):64-69.

18. Lingeswaran A. Psychiatric curriculum and its impact on the attitude of Indian undergraduate medical students and interns. Indian J Psychol Med 2010;32:119-27.

19. Armstrong G, Kermode M, Shoba R, Sujatha S, Chandra P, Jorm AF. A mental health training program for community health workers in India: impact on knowledge and attitudes. International Journal of Mental Health Systems 2011;5:17-23.

20. NHS (UK). Attitude to mental illness 2011 Survey Reports, NHS 2011; NHS Information Center Mental Health and Community ; 2011.

21. Amber V, Reza M. Peer-Level Patient Presenters Decrease Pharmacy Students' Social Distance from Patients with Schizophrenia and Clinical Depression. Am J Pharm Educ 2008;72(5):106-10.

22. Dixon RP, Roberts LM, Lawrie S, Jones LA, Humphreys MS. Medical students' attitudes to psychiatric illness in primary care. Med Educn 2008;42(11):1080-7.

23. Angermeyer M.C., A. Holzinger, H. Matschinger. Mental healthliteracy and attitude towards people with mental illness: A trend analysis based on population surveys in the eastern part of Germany. Eur Psychiatry 2009;24(4):225-232.

24. Leiderman EA, Gustavo V, Candela B, Bonifacio A, Bruscoli N, Capria J, Ehrenhaus B, Guerrero M, Lolich M. Public knowledge, beliefs and attitudes towards patients with schizophrenia: Buenos Aires. Soc Psych Psychiatr Epidemiol 2011;46(4):281-90.

25. Manickam LSS. Training Community Voluteers in Preventing Alcoholism and Drug Addiction : A Basic Programme and Its Impact on Certain Variables Indian J Psychiatry 1997;39:220-5.

26. Corrigan PW, River LP, Lundin R, Penn DL,Uphuff KC, Campion J. Three strategies for changing attributions about severe mental illness. Schizophr Bull 2001;27:187-95.

$$
\begin{aligned}
& \text { Acknowledgements - Nil } \\
& \text { Source of Funding - Nil } \\
& \text { Conflict of Interest - Nil }
\end{aligned}
$$

